\title{
Involvement in research and development projects among community-working occupational therapists in Norway
}

Authors: Tore Bonsaksen ${ }^{1,2}$ (tore.bonsaksen@oslomet.no), Anne-Stine Dolva ${ }^{3}$ (annestine.dolva@inn.no), Cathrine Hagby ${ }^{4}$ (cathrine.hagby@nav.no), Unni Sveen ${ }^{1,5}$ (unni.sveen@oslomet.no), Sissel Horghagen ${ }^{6}$ (sissel.horghagen@ntnu.no), Else Merete Thyness $^{7}$ (else.merete.thyness@ergoterapeutene.no), \& Cathrine Arntzen ${ }^{8,9}$ (cathrine.arntzen@uit.no)

Institutional affiliations:

${ }^{1}$ OsloMet - Oslo Metropolitan University, Department of occupational therapy, prosthetics and orthotics, Faculty of health sciences, Oslo, Norway

${ }^{2}$ VID Specialized University, Faculty of health studies, Sandnes, Norway

${ }^{3}$ Inland Norway University College of Applied Sciences, Lillehammer, Norway ${ }^{4}$ NAV Assistive Aid Central Buskerud, Drammen, Norway

${ }^{5}$ Oslo University Hospital, Department of Physical Medicine and Rehabilitation, Oslo, Norway

${ }^{6}$ Norwegian University of Science and Technology, Trondheim, Norway

${ }^{7}$ Ergoterapeutene - the Norwegian Occupational Therapy Association, Oslo, Norway

${ }^{8} \mathrm{UiT}$ - the Arctic University of Norway, Troms $\varnothing$, Norway

${ }^{9}$ University Hospital of North Norway, Troms $\varnothing$, Norway 
Corresponding author: Tore Bonsaksen, OsloMet - Oslo Metropolitan University,

Department of occupational therapy, prosthetics and orthotics, Faculty of Health Sciences, PO

Box 4 St. Olavs Plass, 0130 Oslo, NORWAY. E-mail tore.bonsaksen@oslomet.no tel. +47

67236611.

Funding: The study received funding from Ergoterapeutene (the Norwegian Occupational Therapy Association).

Disclosure of interest: The authors report no conflict of interest. 


\begin{abstract}
A cross-sectional descriptive survey was conducted $(n=561)$. Almost half of the participants took part in research and development projects. Being involved in research and development was associated with lower age, having further education, and higher levels of work experience. The current and prioritized research topics were reablement and assistive technology. The study implies that community-working occupational therapists are largely involved in research and development, or eager to become involved.
\end{abstract}

Keywords: assistive technology, community-based, project involvement, reablement, research and development 
In Norway, the organization of healthcare services is changing (Department of Health, 20082009), and the ongoing changes are instigated by a combination of factors. First, the demographic composition of the population has more people reaching the older age groups (Andreassen, 2010). Second, the illness panorama in the population has evolved over the last decades (Norwegian Institute of Public Health, 2014). Fewer people have conditions that require high-intensity hospital treatment, whereas an increasing number of people are affected by long-term or chronic illnesses that require competent self-management and low-intensity healthcare services in the communities (Lerdal \& Fagermoen, 2011). In fact, Aas and Grotle (2007) investigated sociodemographic and clinical characteristics of clients using communitybased occupational therapy services and found that numerous types of chronic and severe diseases were represented with some disorders resulting in musculoskeletal impairment, activity limitations as well as participation restrictions. Third, in relation to changes in the population, there is a political drive towards increasing the extent and quality of communitybased health services in the municipalities (Department of Health, 2008-2009; Hagen, 2011). Accordingly, the time spent in hospitals should be reduced to a minimum, and healthcare should largely be provided in the patients' local context.

An increasing proportion of services will be provided in the communities. These changes are expected to have marked implications for occupational therapists over the next few years (Arntzen et al., 2018; Dolva et al., 2018; Stigen, Bjørk, \& Lund, 2018; Stigen, Bjørk, Lund, \& Småstuen, 2018). Moreover, since 2020 will be the year of transition from being an optional to becoming a mandatory municipal service (The Parliament's committee for health, 2015-2016), there will be an increased need for occupational therapists in the municipalities and the general transfer of tasks from hospital-based to community-based services will require community-working occupational therapists to adapt. Adaptation can be enhanced by increasing competence in relevant areas and by playing a part in shaping 
community-based services for the future. To meet the changing demands, therapists also need to be able to communicate and interact effectively with a range of user groups and professional groups (Dolva et al., 2018).

In response to the changing context of healthcare practice in the municipalities, novel ways of organizing and delivering community-based occupational therapy services need to be developed and researched. Related to this need, two issues arise. Identifying what aspects of community-based services are explored among the municipality-working occupational therapists themselves is related, although not identical, to asking about research priorities. In 2015, research priorities were investigated among mental health clinicians in Australia (Hitch \& Lhuede, 2015). It was found that clinicians had four main research priorities: working in an occupation-focused way, clients' experience of therapy groups, factors that may increase clients' engagement in occupation, and engaging patients who are admitted to inpatient wards in meaningful and positive occupation. In Norway, a similar study of municipality-working occupational therapists revealed that several areas were perceived as needing increased research efforts (Gramstad \& Nilsen, 2017). Specifically, studies concerned with cognitive impairments, assistive technology, chronic fatigue, and the cost-effectiveness of occupational therapy services and reablement were highly prioritized in the sample. Reablement is synonymous to the term 'restorative care', which is more commonly used in the USA (Baker, Gottschalk, Eng, Weber, \& Tinetti, 2001), and describes home-based, goal-oriented intervention provided by a coordinated multidisciplinary team to home-dwelling elderly with functional decline. However, studies of community-working occupational therapists' involvement in research and development activities appear to be lacking.

While 'research' refers to the systematic inquiry to obtain new knowledge, 'development' generally refers to the systematic application of existing knowledge to develop or improve processes or products. Thus, while research might produce knowledge concerning 
the effects of an intervention, development would be needed to translate this knowledge into new modes of practice in clinical settings. Notwithstanding their differences, we have not come across research studies that have examined factors associated with occupational therapists' involvement in either research or development projects. Involvement in research and development activities is needed if the profession is to increase its overall research capacity. Increasing the capacity for research is consistent with the explicit priorities in the USA (American Occupational Therapy Association, 2011), and is the aim of a currently undertaken project within the World Federation of Occupational Therapists (World Federation of Occupational Therapists, 2018). For individual therapists, involvement in research and development is often desirable, since the process of carrying out such tasks is highly autonomous and the resulting knowledge is generally empowering for those who can access it. However, occupational therapists' access to groups within which research and development is conducted is likely to be restricted. Formal education and competence give cause to such restrictions (Molander \& Terum, 2008), but there may also be other mechanisms involved in deciding who gets to participate in research and development, and who does not.

As a first step toward building research on occupational therapy in community-based practice, one might study the occupational therapists' own involvement in research and development activities. Considering the nature of higher education; that is, qualifying for complex and demanding tasks that require a substantial level of self-reflection and independence (Molander \& Terum, 2008), one might assume that higher levels of education would increase the possibility of joining a research group or taking a role in a development project. Similarly, more work experience also increases competence, and would likely improve the prospects of becoming part of such developmental activities. However, these are assumptions needed to be tested empirically. Thus, the primary aim of the study was to 
investigate involvement in research and development projects, and factors associated with such involvement, among community-working occupational therapists in Norway. Secondly, we aimed to classify and rank topics for ongoing and desired research and development projects according to their frequency.

\section{Methods}

\section{Design}

The study had a cross-sectional survey design, and is a sub-study of a larger survey conducted in May 2017 (Dolva et al., 2018). Participants were informed that participation was voluntary and anonymous, and completing the survey was considered informed consent. Approval for the study was obtained from the Norwegian Centre for Research Data (project number 52827).

\section{Participants}

Participants were occupational therapists working in community-based practice in Norway. The inclusion criterion 'working in community-based practice' implied being employed by a municipality (local public administration level, like a city or a district), or by a subsection of a municipality with a wide range of tasks and work areas included. Community-based practice would be consistent with practicing mostly in clinical settings, while a minority of the participants would also be involved in managerial tasks (Dolva et al., 2018).

The membership list of Ergoterapeutene (the Norwegian Association of Occupational Therapists) was used to identify relevant participants. Request for participation was sent to 1767 of the 1833 occupational therapists known from the member list to be eligible for participation, the difference owing invalid e-mail addresses of recipients, possibly a result of recent changes in employment. Of the 1767,561 occupational therapists $(31.8 \%)$ opted to participate in the study. The age and gender distribution in the sample $(M=42.2$ years, $S D=$ 
11.5 years, age range 22-66 years, $92.9 \%$ women) was similar to that of the identified population $(M=41.2$ years, $S D=11.7$ years, age range $22-68$ years, $92.0 \%$ women). Thus, in these respects we considered the population to be well represented by the sample who took part in the survey.

\section{The survey}

Based on the ongoing changes in Norwegian healthcare, with more emphasis being placed on community-based services, a questionnaire was developed to explore a range of aspects related to the practice and context of community-working occupational therapists. The development of the survey tool was based on the researchers' literature review and experience as researchers and therapists, and the tool is available from the authors upon reasonable request. The survey topics covered sociodemographic information, education level, work experience, aspects related to the municipalities, and aspects of the participants' practice and interprofessional collaboration. A draft of the questionnaire was set in "EasyFact", an electronic survey program. Seven randomly chosen occupational therapists working in rural or urban community practices agreed to pretest the electronic draft version of the questionnaire. Based on their experiences the questionnaire was revised. The revisions included adding more questions and probes; ensuring that all relevant response options were included; and phrasing of questions to prevent ambiguity. On behalf of the project group, an e-mail with link to the online survey and invitation to participate was sent through Ergoterapeutene. Two reminders were given to non-responders to the initial survey distribution, after one and two weeks, respectively. The survey was closed after three weeks, and all data were transferred to the project group.

\section{Measures}

Age and work experience was registered in years (continuous variable). However, for the multivariate analysis (see below) these were transformed into categorical variables with 
several levels. Age was transformed into age groups $\leq 30$ years (1), 31-40 years (2), 41-50 years (3), 51-60 years (4), and $\geq 61$ years (5). Work experience was transformed into groups with experience $\leq 5$ years (1), 6-10 years (2), 11-15 years (3), 16-20 years (4), 21-25 years (5), 26-30 years (6), and $\geq 31$ years (7). The remaining variables were registered as dichotomous, categorical variables: Gender $($ male $=0$, female $=1)$, education level (bachelor's level $=0$, master's level $=1)$, having further education $($ no $=0$, yes $=1)$, job change during the last year (no $=0$, yes $=1$ ), physically located together with other occupational therapists $($ no $=0$, yes $=1)$, and full-time employment $($ no $=0$, yes $=1)$. In the Norwegian context, 'having further education' means having completed more higher education after the completion of the bachelor's degree education program, although not a full master's degree program. All Norwegian occupational therapy education programs are threeyear undergraduate level (bachelor's degree) programs.

Involvement in research and/or development project was measured with the participants' response to the question: "Do you take part in research and/or development projects as part of your current employment?” Affirming responses indicating involvement was coded 1, whereas non-affirming responses indicating non-involvement was coded 0 . Similarly, being leader of the project was coded 1, whereas not being the project leader was coded 0 . Those currently involved in project work were asked one open-ended question: "What is the topic of your current project?" Those not involved in project work were asked whether or not they would like to be involved in such work (no $=0$, yes $=1$ ), and those wanting to be involved were asked to state which topic they would like to explore in their desired project (open-ended question).

\section{Data analysis}

The computer program SPSS for Windows was used for all statistical analyses (IBM Corporation, 2016). The data were analyzed descriptively, using frequencies and percentages 
for categorical variables and means and standard deviations for continuous variables. To investigate differences between occupational therapists participating in development projects and those who did not, independent $t$-tests and Chi-square tests were used for continuous and categorical variables, respectively. A multivariate logistic regression analysis was performed, using development project involvement as outcome and all of the independent variables entered in one block: age (categorical), gender, further education, work experience (categorical), job change during the last year, job location together with other occupational therapists, and full-time employment. The purpose of this analysis was to assess how change in each of the independent variables would increase or decrease the odds of being involved in research or development project work, while adjusting for the effect of the other independent variables. Effect sizes in the logistic regression analysis were calculated as odds ratio (OR). The level of significance was set at $p<0.05$. To the open-ended questions, a content analysis was performed with the aim of reducing a large number of response categories into fewer, higher-level categories. Subsequently, the resulting categories were ranked according to their frequency.

\section{Results}

\section{Group comparisons}

Two hundred and forty-five participants $(43.7 \%)$ reported that they were involved in research and development project work as part of their current job. Of these, 74 (30.2\%) reported being the leader of the project. In Table 1, participants who were involved in a project are compared against those who were not. Compared to those not involved in research and development project work, those who were involved were older $(p<0.05)$ and had more work experience $(p<0.001)$. They had more often further education $(p<0.001)$ and had more often full time employment $(p<0.05)$. 


\section{TABLE 1 ABOUT HERE}

\section{Adjusted associations with involvement}

The results from the multivariate logistic regression analysis is shown in Table 2 . The full model was statistically significant. Three variables were directly related to involvement in research and development project work, while controlling for the effects of the remaining variables. The odds for being involved in project work decreased by each increase in age group $(\mathrm{OR}=0.68, p<0.01)$ whereas the odds increased by having further education $(\mathrm{OR}=$ $2.66, p<0.001)$ and by higher levels of work experience $(\mathrm{OR}=1.44, p<0.001)$.

\section{TABLE 2 ABOUT HERE}

\section{Categories of current projects}

Table 3 shows the results of the content analysis and displays categories, areas and examples of the projects in which the 245 participants were involved. Six participants did not state their project topic, rendering 239 responses for analysis. Eight categories were classified and ranked, including one category of 'other'. The three most frequently occurring project categories were community-based services, reablement and assistive technology.

\section{TABLE 3 ABOUT HERE}

\section{Categories of desired projects}

Of the 316 participants not currently involved in project work, $220(69.6 \%)$ reported that they wanted to be involved in such work. Table 4 shows the results of the content analysis related 
to desired topics for projects among the participants who wanted to become involved. One hundred and two participants $(46.4 \%)$ did not respond to the question concerning desired project topic, rendering 118 responses for analysis. Nine topic categories were classified and ranked, including one category of 'other'. The three most frequently occurring topics were reablement, assistive technology, and children and youth.

\section{TABLE 4 ABOUT HERE}

\section{Discussion}

This study aimed to investigate involvement in research and development projects among community-working occupational therapists in Norway. We found that almost half (43.7\%) of the participants took part in such activities, whereas just over half of them (56.3\%) did not. Of those who did not participate, a majority (69.6\%) wanted to become involved. Being involved in project work was associated with lower age, having further education, and higher levels of work experience. Reablement and assistive technology were current topics for research and development projects among those who were involved in such projects, and prioritized topics among those who were not.

The ongoing developments in the healthcare sector in Norway implies that many of the tasks traditionally solved within the hospitals are, to an increasing extent, transferred to the municipalities (Department of Health, 2008-2009). High quality occupational therapy practice should be based on research and development (Taylor, 2007), and the same applies to the provision of high quality occupational therapy services in the municipalities. Due to the lack of comparable research studies, the interpretation of the study results is not straightforward. However, it appears positive that almost half of the sample reported that they took part in ongoing research and development projects, and that $30 \%$ of those participating 
reported to be the project leader. Yet another uplifting aspect is that as many as $70 \%$ of those not participating in project work, had a desire to do so. Since project-oriented work is often considered an extra burden, adding to the occupational therapists' workload (Arntzen et al., 2018), this is a positive outcome. . For service leaders and managers in the municipalities, this indicates that, in general, occupational therapists in community-based practice possess motivation to get involved, and stay involved, in research and development efforts related to their current practice. It might also be important to sustain the occupational therapists' motivation by providing opportunities for their involvement in such activities.

In line with the expectations, involvement in project work was associated with having further education and higher levels of work experience. Formal education indicates a certain level of competence, and as such, it is supposed to ease the person's way into tasks that require higher levels of knowledge and skills (Molander \& Terum, 2008) including research and development projects. As opposed to the mainly theoretical competence that comes from formal higher education, work experience is the main route to practical, experience-based competence. However, both forms of acquiring competence are valuable starting points for research and development projects. In fact, collaboration between academics and practitioners on concrete projects has in several countries been viewed as particularly valuable for developing partnerships between different segments of the profession, and for reducing the research-practice gap (Bonsaksen, Celo, Myraunet, Granå, \& Ellingham, 2013; Brown, 1994; Crist \& Kielhofner, 2005; Crist, Muñoz, Hansen, Benson, \& Provident, 2005; Kielhofner, 2005a; Kielhofner, 2005b; Pranger \& Brown, 1990). Thus, the detected associations between further education, more work experience, and project involvement seem logical.

Having a master's degree, however, was not significantly associated with participating in research and development. Although this could be viewed as surprising, it should be noted that the number of participants in the sample holding a master's degree was small (see Table 
1). The absent association between higher educational degree and involvement in research and development may therefore be a random effect of the sample composition (Bowling, 2009). As more master's degree programs relevant for Norwegian occupational therapists have developed lately, in particular master's degree programs in occupational therapy and occupational science, we would expect more occupational therapists in the country to obtain a master's degree over the next few years. Future research may explore the impact of a higher educational degree on the occupational therapists' composition of work assignments.

On the other hand, lower age group was associated with involvement in project work among the participants (see Table 2). For each increase in age group, the odds for reporting project involvement decreased by $32 \%$. Thus, notwithstanding the apparently logical association between higher age and more work experience, only work experience was associated with increased chances of project involvement. In and of itself, higher age decreased the chances. The negative association might be explained by different attitudes toward self-presentation and self-promotion in different age groups. Older persons may be more modest in their self-presentation compared to younger persons, and may therefore be more reluctant towards taking on tasks and positions in research and development. Moreover, the content of, and expectations related to, occupational therapy education have evolved over the decades. Thus, older therapists who received their education many years ago may not have been expected to become involved in research or development.

Alternatively, the association might be explained by a lower level of capacity or ambition among older participants. Involvement in research and development projects often involves working long hours and with a tight schedule to be able to fit in all of the desired activities. The capacity, as well as the motivational drive to work hard in order to pursue ambitions, may have been lower among the older participants. Ambition and generativity among the younger participants, and perhaps reconciliation with status quo and the goals 
already achieved among the older participants, would be in line with psychological development theory (Erikson, 1980). However, in the perspective of what would benefit community-dwelling clients most, it would be important to integrate the ambition and drive among the young with the experience and clinical wisdom of the older. Service leaders and managers may need to consider how they can assist older occupational therapists, who may be more inclined to disengage from research and development initiatives, to re-engage and provide their input to new developments.

Reablement and assistive technology were prioritized topics for research and development projects in both sample subgroups - among those who were involved in research and development projects, and among those who were not involved (see Tables 3 and 4). These priorities diverged from those of Australian mental health clinicians who focused more strongly on how to increase clients' occupational engagement, and on occupation-focused practice (Hitch \& Lhuede, 2015). This might reflect differences in theoretical orientation. There is a strong focus on occupational science in Australia, whereas reablement has become a powerful movement in Norway.

However, our results support those from previous Norwegian research, where reablement and assistive technology were two of the six topics that obtained the highest priority score among the municipality-working participants (Gramstad \& Nilsen, 2017). Conceptually, 'priorities for future research in the municipalities' (Gramstad \& Nilsen, 2017) resembles the information provided in Table 4, consisting of topics for potential projects that those not involved in research and development would like to get involved in. As demonstrated, two of the previously established topics were reiterated by the current study results. This solidifies the importance of these topics for future research on community-based occupational therapy in Norway. We recommend the other topics to be treated with more caution. 
Working with assistive devices may feel burdensome because it can easily transform into the occupational therapist's primary identifying characteristic (Arntzen et al., 2018), instead of adding to the occupational therapist's available methods. Moreover, Dolva and coworkers (2018) showed that among those working with assistive technology in the municipalities, the participants did so during more than $50 \%$ of their working hours. Nonetheless, assistive devices were one of the top prioritized research topics among the community-working sample (Table 4), and one of the most frequent topics for currently ongoing projects (Table 3). This paradox may indicate that the municipality-working occupational therapists are fully aware of 'the trap' aspect of assistive devices and are therefore not afraid of exploring and using them as a topic for their research and development projects. Emphasizing assistive devices as an important part of the research agenda in community-based occupational therapy may also be aligned with the rapid and successful growth of reablement in Norwegian communities during the preceding years (Tuntland, Aaslund, Espehaug, Forland, \& Kjeken, 2015; Tuntland \& Ness, 2014).

\section{Study strengths and limitations}

The study employed a cross-sectional research design, with its inherent limitations. The survey tool was developed specifically for this study, and several of the questions have not previously been used in research. However, a pilot study $(n=7)$ was conducted to ensure that the questions and response options were relevant and appropriate, and the participants' suggestions were largely incorporated into the survey before collecting the data for the main study. The sample size was considered appropriate for the performed analyses, whereas the response rate $(32 \%)$ was rather low. It was, however, similar to the response rate obtained in a previous member survey (Hagby et al., 2014; Horghagen et al., 2015), and it is the response rate that is generally hoped for in large population surveys (Schou-Bredal et al., 2017). Response rates at this level do not necessarily reduce the validity of the data, as previously 
shown (Holbrook, Krosnick, \& Pfent, 2007). In fact, it is clear that those involved in projects may have been more motivated to answer the survey than those who are not, creating an inherent bias. The data were also based on the participants' self-report, which may produce biased results. For example, it may be easier to state on a survey that one wants to be involved in research and/or development, than it is to actually do it.

\section{Conclusion}

Almost half of the participants took part in research and development activities, whereas a slightly larger proportion did not. Being involved in research and development was associated with lower age, having further education, and higher levels of work experience. Among the participants, current as well as prioritized topics for research and development projects were reablement and assistive technology. The study implies that community-working occupational therapists are largely involved, or eager to become involved, in research and development. This resonates well with the rapid changes taking place in community-based services in the country. Future international studies of occupational therapists' involvement in research and development may need to consider the findings in light of local needs and circumstances, and in light of internationally established standards, programs and priorities. To increase the growth and success of occupational therapy research and development, it might be beneficial to negotiate their aims and methods such that they meet pressing local needs while still relating to the strategic needs of the profession. 


\section{References}

Aas, R. W., \& Grotle, M. (2007). Clients using community occupational therapy services: Sociodemographic factors and the occurrence of diseases and disabilities. Scandinavian Journal of Occupational Therapy, 14(3), 150-159. doi:10.1080/11038120600968811

American Occupational Therapy Association. (2011). Occupational therapy research agenda. American Journal of Occupational Therapy, 65(6_Supplement), S4-S7. doi:10.5014/ajot.2011.65S4

Andreassen, K. K. (2010). Befolkningens størrelse og alderssammensetning [The population's size and age distribution]. Accessed April 20, 2018, from http://www.ssb.no/a/publikasjoner/pdf/sa120/kap1.pdf

Arntzen, C., Sveen, U., Hagby, C., Bonsaksen, T., Dolva, A.-S., Thyness, E. M., \& Horghagen, S. (2018). Community-based occupational therapy in Norway: Content, dilemmas, and priorities (manuscript in revision). Scandinavian Journal of Occupational Therapy.

Baker, D. I., Gottschalk, M., Eng, C., Weber, S., \& Tinetti, M. E. (2001). The design and implementation of a restorative care model for home care. The Gerontologist, 41(2), 257-263. doi:10.1093/geront/41.2.257

Bonsaksen, T., Celo, C., Myraunet, I., Granå, K. E., \& Ellingham, B. (2013). Promoting academic-practice partnerships through students' practice placement. International Journal of Therapy and Rehabilitation, 20(1), 33-39.

Bowling, A. (2009). Research methods in health (3 ed.). Buckingham: Open University Press.

Brown, G. T. (1994). Collaborative research between clinicians and academics: Necessary conditions, advantages and potential difficulties. Australian Occupational Therapy Journal, 41(1), 19-26. doi:10.1111/j.1440-1630.1994.tb01807.x 
Crist, P., \& Kielhofner, G. (Eds.). (2005). The scholarship of practice. Academic-practice collaborations for promoting occupational therapy. New York: The Haworth Press Inc.

Crist, P., Muñoz, J. P., Hansen, A. M. W., Benson, J., \& Provident, I. (2005). The practicescholar program: An academic-practice partnership to promote the scholarship of 'best practices'. Occupational Therapy in Health Care, 19(1/2), 71-93. doi:10.1300/J003v19n01_06

Department of Health. (2008-2009). St.Meld. 47: Samhandlingsreformen [Report to Parliament 47: The Coordination Act Reform]. Oslo: Department of Health.

Dolva, A. S., Bonsaksen, T., Horghagen, S., Sveen, U., Hagby, C., Thyness, E. M., . . . Arntzen, C. (2018). Characteristics of community-based occupational therapy: Results of a Norwegian survey (manuscript in revision). Scandinavian Journal of Occupational Therapy.

Erikson, E. H. (1980). Identity and the life cycle. New York: Norton.

Gramstad, A., \& Nilsen, R. (2017). Prioriterte områder for forskning blant kommuneergoterapeuter i Norge [Areas of research prioritized among communityworking occupational therapists in Norway]. Ergoterapeuten, 60(3), 36-45.

Hagby, C., Bonsaksen, T., Dolva, A. S., Horghagen, S., Sveen, U., Solbakken, A. I., \& Thyness, E. M. (2014). Bruker norske ergoterapeuter undersøkelses- og vurderingsredskaper? Resultater fra medlemsundersøkelsen i 2013: Del 1 [Do Norwegian occupational therapists use assessment tools? Results from the member survey 2013: Part I]. Ergoterapeuten, 57(4), 22-27.

Hagen, K. (2011). Innovasjon i omsorg: utredning fra utvalg oppnevnt ved kongelig resolusjon av 26. juni 2009 [Care innovation: Exploration from the committee appointed by Royal Decree of 26 June 2009]. Oslo: The Government. 
Hitch, D., \& Lhuede, K. (2015). Research priorities in mental health occupational therapy: A study of clinician perspectives. Australian Occupational Therapy Journal, 62(5), 326332. doi:doi:10.1111/1440-1630.12223

Holbrook, A. L., Krosnick, J. A., \& Pfent, A. (2007). The causes and consequences of response rates in surveys by the news media and government contractor survey research firms. In J. Lepkowski, C. Tucker, J. M. Brick, E. D. de Leeuw, L. Japec, P. J. Lavrakas, M. W. Link, \& R. L. Sangster (Eds.), Advances in telephone survey methodology (pp. 499-528). New York: John Wiley \& Sons.

Horghagen, S., Bonsaksen, T., Dolva, A. S., Hagby, C., Solbakken, A. I., Sveen, U., \& Thyness, E. M. (2015). På vei inn i en kunnskapsbasert praksis: Ergoterapeuters begrunnelser for bruk eller ikke bruk av vurderingsredskaper [Moving towards evidence-based practice: Occupational therapists' rationale for using or for not using assessment tools]. Ergoterapeuten, 58(6), 48-59.

IBM Corporation. (2016). SPSS for Windows, version 24. Armonk, NY: IBM Corp.

Kielhofner, G. (2005a). Scholarship and practice: Bridging the divide. American Journal of Occupational Therapy, 59(2), 231-239.

Kielhofner, G. (2005b). A scholarship of practice: Creating discourse between theory, research and practice. Occupational Therapy in Health Care, 19(1/2), 7-16. doi:10.1300/J003v19n01_02

Lerdal, A., \& Fagermoen, M. S. (Eds.). (2011). Laering og mestring - et helsefremmende perspektiv i praksis og forskning [Learning and mastery - a health promotion perspective in practice and research]. Oslo: Gyldendal Norsk Forlag AS.

Molander, A., \& Terum, L. I. (Eds.). (2008). Profesjonsstudier [Studies of professions]. Oslo: Universitetsforlaget. 
Norwegian Institute of Public Health. (2014). Helsetilstanden i Norge [The health condition in Norway] Oslo: Norwegian Institute of Public Health

Pranger, T., \& Brown, G. T. (1990). Collaborative research: Campus and clinic working together. Canadian Journal of Occupational Therapy, 57(5), 268-272.

Schou-Bredal, I., Heir, T., Skogstad, L., Bonsaksen, T., Lerdal, A., Grimholt, T. K., \& Ekeberg, Ø. (2017). Population-based norms of the Life Orientation Test Revised (LOT-R). International Journal of Clinical and Health Psychology, 17(3), 216-224. doi:10.1016/j.ijchp.2017.07.005

Stigen, L., Bjørk, E., \& Lund, A. (2018). The conflicted practice: Municipal occupational therapists' experiences with assessment of clients with cognitive impairments (early online). Scandinavian Journal of Occupational Therapy, 1-12. doi:10.1080/11038128.2018.1445778

Stigen, L., Bjørk, E., Lund, A., \& Småstuen, M. C. (2018). Assessment of clients with cognitive impairments: A survey of Norwegian occupational therapists in municipal practice. Scandinavian Journal of Occupational Therapy, 25(2), 88-98. doi:10.1080/11038128.2016.1272633

Taylor, M. C. (2007). Evidence-based practice for occupational therapists (2 ed.). Oxford: Blackwell Publishing.

The Parliament's committee for health. (2015-2016). Innst. 40 S (2015-2016): Innstilling til Stortinget fra helse- og omsorgskomiteen om fremtidens primærhelsetjeneste - nærhet og helhet [Prop. 40S (2015-2016): Proposition to the Parliament from the Health and Care Committee on the primary healthcare services of the future - proximity and holism]. Oslo: The Government. 
Tuntland, H., Aaslund, M. K., Espehaug, B., Forland, O., \& Kjeken, I. (2015). Reablement in community-dwelling older adults: a randomised controlled trial. BMC Geriatrics, 15, 145. doi:10.1186/s12877-015-0142-9

Tuntland, H., \& Ness, N. E. (2014). Hverdagsrehabilitering [Reablement]. Oslo: Gyldendal. World Federation of Occupational Therapists (2018). Programme areas. Accessed June 26, 2018, from http://www.wfot.org/AboutUs/ManagementStructureOrganisation/ProgrammeAreas.as px 
Table 1

Characteristics of the study sample $(n=561)$

\begin{tabular}{lccc}
\hline Variables & $\begin{array}{c}\text { Involved in project } \\
(n=245)\end{array}$ & $\begin{array}{c}\text { Not involved in project } \\
(n=316)\end{array}$ & $p$ \\
\hline Age (years) & $\frac{M(S D)}{M(S D)}$ & 0.03 \\
Work experience (years) & $43.4(11.3)$ & $41.3(11.7)$ & $<0.001$ \\
& $18.5(10.0)$ & $14.9(9.5)$ & \\
Female gender & $\underline{n(\%)}$ & $\underline{n(\%)}$ & 0.88 \\
Master's level education & $228(93.1)$ & $293(92.7)$ & 0.36 \\
Further education & $16(6.5)$ & $15(4.7)$ & $<0.001$ \\
Job change during last year & $168(68.6)$ & $131(41.5)$ & 0.41 \\
Located together with other OTs & $55(22.4)$ & $62(19.6)$ & 0.45 \\
Full-time employment & $160(65.3)$ & $216(68.4)$ & 0.02
\end{tabular}

Note. Statistical tests are independent $t$-tests for continuous variables and Chi-square tests for categorical variables. 
Table 2

Multivariate logistic regression analysis showing associations between the study variables and involvement in project work $(n=561)$

\begin{tabular}{|c|c|c|c|c|}
\hline & \multicolumn{4}{|c|}{ Adjusted model } \\
\hline Independent variables & $\underline{\mathrm{B}(\mathrm{SE})}$ & $\underline{\text { Wald }}$ & $\underline{\mathrm{OR}}$ & $95 \% \mathrm{CI}$ \\
\hline Age group & $-0.39 *(0.14)$ & 7.61 & 0.68 & $0.51-0.89$ \\
\hline Gender & $-0.02(0.36)$ & 0.00 & 0.98 & $0.49-1.97$ \\
\hline Education level & $-0.21(0.39)$ & 0.30 & 0.81 & $0.37-1.74$ \\
\hline Further education & $0.98 * *(0.20)$ & 24.89 & 2.66 & $1.81-3.90$ \\
\hline Work experience & $0.37 * *(0.09)$ & 16.56 & 1.44 & $1.21-1.72$ \\
\hline Job change & $0.39(0.23)$ & 2.83 & 1.48 & $0.94-2.32$ \\
\hline Located together with other OTs & $-0.15(0.19)$ & 0.59 & 0.86 & $0.59-1.26$ \\
\hline Full-time employment & $0.36(0.22)$ & 2.69 & 1.44 & $0.93-2.22$ \\
\hline
\end{tabular}

Note. Adjusted model parameters: Nagelkerke $\mathrm{R}^{2}=0.15$, Cox \& Snell $\mathrm{R}^{2}=0.11$, Model $\chi^{2}=65.018, p<0.001$. Reference categories for the independent variables are lower age group, male gender, bachelor level education, no further education, low work experience, no job change last year, not located with other occupational therapists, and not full job.

$* * p<0.001$

$* p<0.01$ 
Table 3

Categories and examples of research and development projects $(n=263)$ in which communityworking occupational therapists were involved

\begin{tabular}{|c|c|c|c|}
\hline Rank (n) & Category & Area & Topic examples \\
\hline \multirow[t]{2}{*}{$1(60)$} & $\begin{array}{l}\text { Community- } \\
\text { based services }\end{array}$ & Occupational therapy & $\begin{array}{l}\text { Planning OT services, procedures, } \\
\text { priorities, interventions }\end{array}$ \\
\hline & & $\begin{array}{l}\text { Interprofessional } \\
\text { service }\end{array}$ & $\begin{array}{l}\text { Teamwork/-roles, coordinating, } \\
\text { patient-lapse, home-based service } \\
\text { Planning services and buildings } \\
\text { (day center, service home, life- } \\
\text { long-standard) }\end{array}$ \\
\hline $2(55)$ & Reablement & $\begin{array}{l}\text { Mastery of everyday } \\
\text { activities }\end{array}$ & $\begin{array}{l}\text { Assessments, nutrition and diets, } \\
\text { activity-friend, active life/physical } \\
\text { activity, social meeting places }\end{array}$ \\
\hline $3(54)$ & $\begin{array}{l}\text { Assistive } \\
\text { technology }\end{array}$ & $\begin{array}{l}\text { Assistive technology } \\
\text { and devices }\end{array}$ & $\begin{array}{l}\text { Distribution and service, visual } \\
\text { and hearing technology, } \\
\text { innovation projects (electronic } \\
\text { medicine dispenser, APP's) }\end{array}$ \\
\hline $4(22)$ & Prevention & $\begin{array}{l}\text { Assessments, services } \\
\text { and courses }\end{array}$ & $\begin{array}{l}\text { Prevention of falls, fire, social } \\
\text { isolation }\end{array}$ \\
\hline $5(19)$ & Dementia & $\begin{array}{l}\text { Cognition and } \\
\text { interventions }\end{array}$ & $\begin{array}{l}\text { Assessments, procedures and } \\
\text { programs, dementia and } \\
\text { homebased service, 'faith model', } \\
\text { voluntary assistance }\end{array}$ \\
\hline $6(19)$ & Rehabilitation & $\begin{array}{l}\text { Service and } \\
\text { intervention }\end{array}$ & $\begin{array}{l}\text { Outpatient services, professional } \\
\text { service designing, professional } \\
\text { networks, stroke } \\
\text { rehab/intervention, cancer, } \\
\text { innovative rehabilitation }\end{array}$ \\
\hline $7(14)$ & $\begin{array}{l}\text { Children and } \\
\text { youth }\end{array}$ & $\begin{array}{l}\text { Health, school, } \\
\text { leisure, parents }\end{array}$ & $\begin{array}{l}\text { Developing OT services, } \\
\text { procedures, parental supervision, }\end{array}$ \\
\hline
\end{tabular}


school based OT, health and physical activity, function, obesity 8 (20) Other 'Healthy lives', elderly, universal design, psychiatry, mental health, alcohol and drugs problems etc.

Note. The analysis is based on the responses of participants who reported that they currently were involved in research and development projects. 
Table 4

Categories and examples of projects $(n=145)$ in which community-working occupational therapists would like to become involved

\begin{tabular}{|c|c|c|}
\hline Rank (n) & Category & Topics examples \\
\hline $1(21)$ & Reablement & $\begin{array}{l}\text { In general OT and in combination with } \\
\text { assistive/welfare technology }\end{array}$ \\
\hline $2(19)$ & Assistive technology & In general OT and homebased OT \\
\hline $3(17)$ & Children and youth & $\begin{array}{l}\text { School-based OT, hand function, early } \\
\text { intervention }\end{array}$ \\
\hline $4(15)$ & $\begin{array}{l}\text { Community-based } \\
\text { services }\end{array}$ & $\begin{array}{l}\text { OT service, OT in inter-/multi professional } \\
\text { teamwork }\end{array}$ \\
\hline $5(11)$ & Universal design & $\begin{array}{l}\text { Hearing, mobility, planning of houses and } \\
\text { environments }\end{array}$ \\
\hline $5(11)$ & Rehabilitation & Cancer, work, stroke \\
\hline $7(9)$ & Mental health & Substance abuse, self-efficacy, mastery \\
\hline $8(9)$ & Prevention & Falls, home visiting, supervision \\
\hline $9(40)$ & Other & Different OT projects \\
\hline
\end{tabular}

Note. The analysis is based on the responses of participants who reported that they currently were not involved in research and development projects. 